\title{
The Effectiveness of E-Learning on Students in the Teaching of Children's Literature Subject in Indonesian Language and Literature Study Program
}

\author{
Trisnawati Hutagalung ${ }^{1}$, Diah Eka Sari ${ }^{1}$, Atikah Wasilah ${ }^{1}$ \\ State University of Medan \\ trisnawati.hutagalung@yahoo.co.id
}

\begin{abstract}
This study aimed at determining the effectiveness of learning using edmodo media on students in the course of teaching children's literature. The population in this study were all students of the Indonesian Language Education Study Program class of 2017 and who were sampled were 34 students. This research is using experimental method. The results of the study before using edmodo media in teaching children's literature got an average value of 71.2 with a standard deviation of 17.63 and a standard error of 3.0. After using edmodo media students get an average value of 87.6 with a standard deviation of 10.01 and a standard error of 1.71 .
\end{abstract}

Keywords: media e-learning; edmodo; teaching of children's literature.

\section{Introduction}

The existence of e-learning has a big influence on the learning process. Even many universities that have used e-learning as a tool so that the teaching and learning process can still be carried out without the need of facing each other from both parties. So that the difficulties in the learning process that have only been fixated on meetings in the classroom can be resolve by utilizing the e-learning. For example, when there are limitations to the classroom or time, in which leads to the absence of learning process that should be held.

In general, the use of learning facilities can provide stimulus to students in the learning process, so that it becomes one of the factors in achieving maximum learning outcomes. Having quality graduates are the goal of every institution. Various ways are done to achieve it. One of the ways that the institutions been doing is to improve the quality of learning by utilizing the learning media. There are many types of e-learning media that are active, creative and interesting, one of which is Edmodo's learning media. Edmodo, according to Prayitno and Hidayati (2017: 86) is one application of learning that encourages students to be responsible for their learning activities, as a forum for students to develop their professionalism by utilizing a virtual class, and as a controlling tool for the parents to their children who are studying at school. Edmodo is a social media that supports learning, with the interface that similar to Facebook (Dwiharja, 2015: 333). Therefore, Edmodo is very suitable for the use in learning because the platform is similar tp Facebook which is commonly used by students. Edmodo also facilitates learning activities that can be done anywhere and anytime. By using Edmodo's learning media, not only students can communicate with text, but also with photos, videos and audios so that it can increase the students' interest in following the learning process.

Several studies have shown that the use of Edmodo's learning media can improve the students' quality of learning. One of the studies conducted by Suriadhi, et al (2014) entitled The Development of E-Learning Based on Edmodo in VIII Grade of Science Subjects at Singaraja 2 Public School. The result shows that the use of Edmodo's learning media was very effective to improve learning outcomes of science in VIII grade students in Singaraja 2 public school. In line with the research conducted by Basori (2013) entitled The Utilization of Social Learning Network "Edmodo" in Helping the Lecture on Theory of Automotive Body in 
the PTM JPTK FKIP UNS Study Program. The results of the study showed that (1) there was a significant increase in lectures / learning. It can be seen from the data that $52.94 \%$ is in the high category, and $38.24 \%$ is in the very high category; (2) Students have a high level of satisfaction with this Edmodo service. From the data, can be found that $61.76 \%$ are in very high categories, and $35.29 \%$ are in high category. The similar thing also shows an increase in the level of students' probabilistic thinking conducted by Kurniasih, et al (2016) whose results state that teaching with Edmodo are better for increasing the level of students' probabilistic thinking.

Therefore, based on the explanation above, the researcher is interested in making a research with the problem's formulation on how is the effectiveness of learning uses Edmodo's media for students in the course ofthe teaching of children's literature.

\section{Theoretical Review}

Edmodo was founded in 2008 by Nicolas Brog and Jeff O'Hara. Edmodo according to Bashori (2013) is a microblogging platform specifically developed and designed to be used by teachers and students in a classroom. Edmodo according to Dwiharja (2015: 333) is a social media that supports learning, with the interface that almost similar to Facebook. The same thing was expressed by Suriadhi, et al (2014) in his journal entitled The Development of E-Learning Based on Edmodo in VIII Grade of Science Subjects at Singaraja 2 Public School that Edmodo is a social media platform which is often described as Facebook for schools and can be used as needed. According to Dharmawati in her journal entitled The Use of ELearning Media Based on Edmodo in Learning English for Business that Edmodo is a free service that allows the lecturers to safely create and maintain their own class community. According to Prayitno and Hidayati (2017) Edmodo is one application of learning that encourages students to be responsible for their learning activities, as a forum for students to develop their professionalism by utilizing virtual classes, and as a controlling tool for the parents to their children who are studying at school.

Thus, from some explanations according to the experts above, it can be concluded that Edmodo is an online learning media that resembles Facebook which is used as a forum for students and education personnel in the learning process under the auspices of E-Learning which is not limited by time and space.

\section{Research Methodology}

This research was conducted at the Indonesian Language and Literature Study Program, Faculty of Language and Art, State University of Medan in June - October. The method used in this study is a quasi-experimental method with the intention to see the effect or influence of a treatment on the teaching of children's literatureusing Edmodo with the design of one group pretest-posttest design. Arikunto (2006: 211) said that the design of one group pretest-posttest design, which experiments are carried out in one group, we can compare the results of the dependent variable which examined in the students before and after the treatment taken as a solution. The design with this model gives the same treatment to each subject by taking into account the basic capabilities which they possessed. Although there is a possibility that each sample subject has different abilities. In conclusion, students who become the sample will get the same thing, which is the initial test (pretest), and the last test (posttest). 


\section{Result And Discussion}

\section{A. Research Result}

\section{Learning Courses for The Teaching of Children's Literature Before Using Edmodo}

Based on the research results before using Edmodo in the teaching of children's literature, students who scored 27 points were 2 people, 44 pointswere 2 people, 56 pointswere 2 people, 61 points were 1 person, 67 pointswere 4 people, 72 pointswere 13 people, 77 were points 2 people, 89 pointswere 3 people, 94points were 3 people and 100 pointswere 2 people. The total number of students are 34 people. The total value is 2422 with an average value of 71,2 which is relatively low. This can be seen from the acquisition of an average value of 71,2 which is still below the competency standard.

\section{Learning Courses for the Teaching of Children's Literature After Using Edmodo}

Based on the research results after using Edmodo in the teaching of children's literature, students who scored 67points were 1 person, 72points were 3 people, 77points were 6 people, 83 pointswere 3 people, 89 pointswere 6 people, 94 pointswere 8 people, and 100 pointswere 7 people. The total number of students are 34 people. The total value is 2980 with an average value of 87,6 , which is very good. This can be seen from the acquisition of an average value of 87,6 has reached the competency standard.

\section{Learning Courses for the Teaching of Children's Literature After Using \\ Edmodo is more effective than Before Using Edmodo}

Learning courses for the teaching of children's literature after using Edmodo is very effective compared to not using Edmodo. The average value of students before using Edmodo was 71,2 while the students' skills after using Edmodo were 87,6. This shows that after using Edmodo is better than before using Edmodo.

\section{B. Discussion}

\section{Learning Courses for the Teaching of Children's Literature Before Using Edmodo}

Based on the research results conducted at the Indonesian Language Education and Literature Study Program, it can be concluded that the scores obtained by students before using Edmodo were 27 pointsfor the lowest score and 100 pointsthe highest scores. The average score was 71,2 with a standard deviation of 17,63 and standard error by 3,0. This is based on the fact that students have not been given treatment with Edmodo so that the value is low. The teaching of children's literature without using Edmodo falls into five categories namely, very good at $14,7 \%$, good at $8,8 \%$, fair at $44,1 \%$, poor at $14,7 \%$ and very poor at $17,6 \%$. Based on these findings, the results obtained were not the expected results, the results of the teaching of children's literature are still below the competency standards. It can be seen in the following table:

Table 1. The Identification of Tendency in the Results Before Using Edmodo

\begin{tabular}{|l|c|l|l|}
\hline Range & $\begin{array}{l}\text { Absolute } \\
\text { Frequency }\end{array}$ & $\begin{array}{l}\text { Relative } \\
\text { Frequency }\end{array}$ & Category \\
\hline $91-100$ & 5 & $14,7 \%$ & Very Good \\
$81-90$ & 3 & $8,8 \%$ & Good \\
$71-80$ & 15 & $44,1 \%$ & Fair \\
\hline
\end{tabular}




\begin{tabular}{l|r|l|l}
\hline $61-70$ & 5 & $14,7 \%$ & Poor \\
$0-60$ & 6 & $17,6 \%$ & Very Poor \\
\hline & 34 & $100 \%$ & \\
\hline
\end{tabular}

Relative Frequency Formula $=$ Absolute Frequency $:$ the Total of Students x 100\%

\section{Learning Courses for the Teaching of Children's Literature After Using Edmodo}

Based on the research results conducted in the Indonesian Language and Literature Study Program, it can be concluded that the value obtained by students after using Edmodo is 67 pointsfor the lowest score and 100points for the highest score. The average value is 87,6 with a standard deviation of 10,01 and standard error of 1,71. From the data presented, the teaching of children's literature using Edmodo is more effective than not using Edmodo. Children's literature teaching using Edmodo falls into five categories, which are very good $44,12 \%$, good $26,47 \%$, fair $26,47 \%$, poor $2,94 \%$ and very poor $0 \%$. Based on these findings, the results obtained werethe expected results. The teaching of children's literature has reached the competency standards. It can be seen in the following table:

Table 2. The Identification of Tendency in the Results After Using Edmodo

\begin{tabular}{l|l|l|l}
\hline Range & $\begin{array}{l}\text { Absolute } \\
\text { Frequency }\end{array}$ & $\begin{array}{l}\text { Relative } \\
\text { Frequency }\end{array}$ & Category \\
\hline $91-100$ & 15 & $44,12 \%$ & Very Good \\
$81-90$ & 9 & $26,47 \%$ & Good \\
$71-80$ & 9 & $26,47 \%$ & Fair \\
$61-70$ & 1 & $2,94 \%$ & Poor \\
$0-60$ & 0 & $0 \%$ & Very Poor \\
\hline & 34 & $100 \%$ & \\
\hline
\end{tabular}

Relative Frequency Formula $=$ Absolute Frequency $:$ the Total of Students x 100\%

\section{Learning Courses for the Teaching of Children's Literature After Using Edmodo is More Effective than Before Using Edmodo}

Based on the two results above, it can be concluded that the teaching of children's literature after using Edmodo is more effective than before using Edmodo. It is proven from the two results above, which show the acquisition of the average value of students before using Edmodo was 71,2 and the teaching of children's literature after using Edmodo was 87,6. It can be concluded that the teaching of children's literature after using Edmodo is more effective than before using Edmodo.

\section{Conclusion}

Based on data analysis after using Edmodo it was found that the overall results were 87,6 with a standard deviation of 10,01 and a standard error of 1,71 of 34 students being sampled. In the normality test after using Edmodo with Liliefors test obtained $\mathrm{L}_{\text {count }}=$ $0,14952>\mathrm{L}_{\text {table }}=0,886$. This shows that identification after using Edmodo is normal because 
the value of students in general is fallen in the very good category. Meanwhile, the average value before using Edmodo is an average of 71,2 with a standard deviation of 17,63 and a standard error of 3,0 with a total of 34 students being sampled. Before using Edmodo, the test used in testing data normality is the same as the formula used after using Edmodo by using the Liliefors test $\mathrm{L}_{\text {count }} 0,16047>\mathrm{L}_{\text {table }} 0,886$ and this proves that the data before using Edmodo is normally distributed. Furthermore, $\mathrm{t}_{\text {count }}=7,56$ then consulted with $\mathrm{t}_{\text {tablesignificant }}$ level $5 \%$ with $\mathrm{df}=\mathrm{N}-1=34-1=33$ obtained a significant level of $5 \%=1,69$. Because $\mathrm{t}_{0}$ is obtained greater than $t_{\text {table }}$ which is 7,56>1,69 then Ha is accepted.

The researcher explained the following suggestions. 1) learning coursesfor the teaching of children's literature using Edmodo is included in the very good category. It can be seen from the data before and after using Edmodo. Edmodo's learning media can be applied by lecturers in learning, especially in the course of the teaching of children's literature. 3) lecturers should add varied learning models and attract students' attention so that the teaching and learning process in the classroom is not monotonous so students do not feel bored and can understand the lesson better.

\section{References}

Arikunto, Suharsimi. 2006. Prosedur Penelitian Suatu Pendekatan Praktik. Jakarta: Rienka Cipta.

Basori. 2013. Pemanfaatan Social Learning Network "Edmodo" dalam Membantu Perkuliahan Teori Bodi Otomotif di Prodi PTM JPTK FKIP UNS. JIPTEK, Vol. VI, No.2, Juli 2013. Hal 99-105.

Dwiharja, Laksmi Mahendrati. 2015. Memanfaatkan Edmodo Sebagai Media Pembelajaran Akuntansi. Surabaya: UNS.

Prayitno, T dan Nurul H. 2017. Pengembangan Multimedia Interaktif Bermuatan Materi Mikrobiologi Berbasis Edmodo Android. JurnalBioilmi, Vol. 3, No. 2, Agustus 2017.Hal $86-93$.

Suriadhi, dkk. 2014. Pengembangan E-Learning Berbasis Edmodo Pada Mata Pelajaran IPA Kelas VIII di SMP Negeri 2 Singaraja. Jurnal Teknologi Pendidikan, Vol. 2, No. 1. 